\title{
Best before... ? The Dutch theatre sound archive between shelf-life and " functional memory »
}

À consommer de préférence avant le... ? Les archives sonores du théâtre néerlandais, de la durée de conservation en stock à la "mémoire fonctionnelle »

\section{Ricarda Franzen}

\section{(Q) OpenEdition}

\section{Journals}

Édition électronique

URL : http://journals.openedition.org/rsl/1119

DOI : $10.4000 /$ rsl. 1119

ISSN : 2271-6246

Éditeur

Éditions Rue d'Ulm

Référence électronique

Ricarda Franzen, «Best before... ? The Dutch theatre sound archive between shelf-life and « functional memory » », Revue Sciences/Lettres [En ligne], 5 | 2017, mis en ligne le 02 octobre 2017, consulté le 30 avril 2019. URL : http://journals.openedition.org/rsl/1119; DOI : 10.4000/rsl.1119

Ce document a été généré automatiquement le 30 avril 2019.

(c) Revue Sciences/Lettres 


\title{
Best before... ? The Dutch theatre sound archive between shelf-life and « functional memory »
}

\author{
À consommer de préférence avant le... ? Les archives sonores du théâtre \\ néerlandais, de la durée de conservation en stock à la " mémoire fonctionnelle "
}

Ricarda Franzen

\section{Theatre sound collection against «vergetelheid» (forgetfulness)}

1 «The foundation Theater Klank en Beeld (Theatre Sound and Image) is in fact a pitiful endeavour. It tries so hard to collect all audio and video documentation of anything that happens on Dutch stages, but it is seriously impeded by lack of money. There is a small amount of subsidy, which at least makes it possible to tape important [sound] fragments of theatre performances. [... $]^{1 »}$ What reads at first glance as a way of raising awareness for a seemingly frail sound archival effort («a pitiful endeavour»), are the first lines of a promotional newspaper article from January 4, 1975, advertising the Dutch theatre sound archive's release of a new LP featuring contemporary theatre performance. Further on, the article subsumes the archive's merits in recording what otherwise might be forgotten. The choice of rhetorical strategies, that could be seen to anticipate some of the archive's existential struggles and its actual decline decades later, sets up central topics for this article: the attempt to counter theatre's ephemerality with the institutionalization of memory in the form of a sound archive, which then in turn itself becomes object to decline in the course of the years. How might the institutional body of a theatre sound archive be said to channel or propel theatre memories? Which role does a theatre sound archive play for collective forms of remembering theatre? This central question results in a three-part structure of this article, each reacting to subsets of further defining 
questions: 1) How is a theatre sound archive conceptualized? 2) Which relationship does theatre have with its auditory heritage? 3) How does auditory memory possibly form? To reduce the vastness of these questions, I find it useful to discuss these questions at the example of the Dutch theatre sound archive «Theater Klank en Beeld» (Theatre Sound and Image), and moreover, as limited in time to its beginning years. I translate the above mentioned question to the case as follows:

- the archive in its institutional context: What kind of archive was the Dutch theatre sound archive in its beginning years? What was the relationship of the archive with its hosting institution?

- How could the relationship of the theatre with its auditory heritage be described for the beginning years? Which selection criteria were revealed? How did the archival selection come into life?

- the relationship of archival institution and memory practices: How might different instances of the use of the sound archive throughout history indicate a certain (dys)functionality of the archive and how might they deal with remembering?

2 The case study of a neglected theatre sound archive motivates a simple dialectic in thinking about the central question on institutional theatre sound memory. So instead of departing from the «dream of linear additive progress ${ }^{2} »$ that might be inherent to all archival hope for the formation of memory, I suggest to work towards its complication by suggesting the metaphor of «limited shelf-life». Through the metaphor of shelf-life I wish to understand particular life-forms on the shelf as limited by or surviving the institutional construction.

3 If I contrast the two metaphorical notions of memory and shelf-life, I see them as part of archiving, - similarly to the double power-relation of «institutive and conservative», as famously theorized by Derrida ${ }^{3}$. To which extent can theatre sound archives institute memory? How can re-uses be regarded in their effect to «functional memory ${ }^{4} »$ ?

\section{The institutional affiliation of the archive «Theater Klank en Beeld» (Theatre Sound and Image) with the overarching Theatre Museum}

4 The sound archive that serves as a case study to this article holds about 32000 items out of which about 5700 are digitized. The holdings comprise next to performance recordings of diverse genres of theatre, also studio reproductions of famous theatre dialogues, cabaret songs, interviews, documentaries or radio dramatizations of theatre texts ${ }^{5}$. The oldest recording in the collection is likely to be the speech of actor Louis Bouwmeester at the wedding of the Dutch Queen in 1901. The archive is part of a comprehensive theatre collection, which is currently hosted by the University of Amsterdam as part of the former theatre institute TIN (Theater Instituut Nederland ${ }^{6}$ ). The university is its latest home base, after in 2013 budget cuts of the Dutch government had effected the dissolution as an independent institution?

5 As an archive, the sound archive co-exists next to other theatre collections including paper archives and archives consisting of collected material from and about theatre performances, theatre personalities, specific theatre opera and dance architecture and puppets, ranging in material from photographs, reviews, posters, audio, video, designs, texts, models to costumes and more. The sound archive itself was rendered inactive about 
two decades before the overarching institution's closure. Items are at this point not exhaustively catalogued or appraised, and the digitization project remains uncompleted.

The sound archive was officially founded in 1965 and since then it has been affiliated with the Theatre Museum (later TIN). The archive's foundation dossier reveals, that legally speaking the sound archive's name was «Stichting Geluid-en Beeldarchief van het Toneelmuseum» (Foundation sound and image archive of the Theatre Museum), which underlines its identification as archive for sound and image with the more encompassing project, the mothering institution.

7 As for the hierarchy of the different material, the independent Dutch museum specialist Riemer Knoop, published an extensive assessment of the TIN under the title «An empty stage. Assessing the Value of Theatrical Collections» (2015). Following the coherence of the institution as a physical house (which in fact was the physical appearance it existed in for a long time in its institutional history), Knoop divides the TIN's several institutes into a public use «front of the house» (library/mediatheek) on the one hand and a «back office» of storage collections ${ }^{8}$. Knoop further divides the archives along active and nonactive lines. The sound archive thus, at the time of assessment in 2013, formed part of the inactive archival storage facility of the back office. Although not making the connection with memory theories himself, Knoop's division neatly coincides with a common characterization and hierarchization of the different institutes in their central role to memory.

Literature on memory ascribes a central role to three of the aforementioned public functions for the formation of collective memory: museums, archives as well as libraries ${ }^{9}$. Memory scholar Aleida Assmann is much quoted in making the differentiation between «storage memory» and «functional memory», as coinciding with the back office definition for storage facilities such as archives and the more curated and selected representations in museums or in cultural processes of selection such as the canon as the functional memory.

9 Which role does the specific sound material play in this? For the case of the Dutch theatre sound archive what made it necessary, possible and beneficial from a historical perspective to record theatre by means of sound?

\section{Dutch theatre voices on the shelf: Theatre sound archival selection policies}

10 For the conceptualization and ideas behind the sound archival institutionalization it is interesting to interject with a discussion of my sources. The material I draw most prominently on are next to the aforementioned article by Knoop (2015) and an archive internal document ${ }^{10}$, the archive's own business archive and publications from the early years of the 1970's of advertising and conceptualization, written by Lou Hoefnagels, who was early on director of the archive ${ }^{11}$. The latter was a sound missionary in multiple reincarnations, one of which was to be founding member of the International Association of Sound and Audiovisual Archives (IASA) ${ }^{12}$. Hoefnagels' articles are passionate, yet pragmatic: Why sound? Hoefnagels confirmed the narrative of a lack of subsidy of the entrance example; in 1972 he still emphasized the costliness of video equipment preventing systematic capturing and documentation of theatre practice ${ }^{13}$. Sound, in contrast, was a timely and relatively affordable medium, and the infrastructure within 
the house of the Theatre Institute in 1971 provided listening cabins in the cellar, accessible all weekdays, and material borrowable for strict non-commercial, educational purposes $^{14}$.

The sound archive was originally an assembly of mainly two types of sound documents, one being already existing donated recordings, the other were newly commissioned sound recordings. And while Hoefnagels devotes a whole section in his 1971 publication to the possibility of discrepancy of institutional vision and the collected material ${ }^{15}$, a look at the own recording practice might be possibly most revealing in terms of the institute's vision. This recording practice, in Hoefnagels' elaborations «the core of the collection ${ }^{16}$ », focused in accordance with the archival effort of its overarching institution on theatre productions mainly ${ }^{17}$. Hoefnagels explains that a selection committee is employed to select the recording of the «best expressions of contemporary performance ${ }^{18} 》$. The founding document from February 1965 reveals that the selection committee («Artistieke Keuzecommissie») was sought to consist of six people, with three being representatives from theatre practice and another three from the archival board. I have not been able to locate any further documentation of the committee's ultimate actual selection rationale. Hoefnagels details possible terms of documentary ambitions of how to identify promising historical uniqueness ${ }^{19}$.

The recordings that were ultimately selected are chronicled in two publications, one being the quinquennial catalogue «Lustrum», the other is the Institute's catalogue called "Amphitheater», sent out to members ten times per year. It becomes clear in these written documentations how initially the sound archive's holdings document text theatre productions, while the more comprehensive five-year-anniversary catalogue next to a prevailing number of text theatre performance recordings also contains conference recordings, exam recordings of theatre students, short documentaries or lectures. The diversification of documentation formats might safely be interpreted as increased confidence and embrace of the sound medium. Was the sound archive possibly conceptualized as the best way to capture the performance of text in the first place? In the edited volume Audioarchive, Kathrin Dreckmann reminds us how sound - before its retention became technically possible - was recorded and understood through the detour of written text ${ }^{20}$. It would need further research to determine how both text centred performance practice in the beginning years of the sound archive as well as the documentary goal might initially have aided to mainly overlook the implications of the medium of sound and consider it according to its documentary goal just equal to photography, thus merely as a memory aid of what still could be remembered otherwise.

Through Hoefnagels' encouragement to document «[t]he pulsating life of the stage performance ${ }^{21} \gg$ decisions might be understood to capture liveness and the uniqueness of contemporary events that were part of everyone's horizon of experience. This framing contrasts with the way researchers have observed the apparently constitutive existentialist rhetoric of saving the archival objects from perishing, for rationales of sound recording from Edison's invention of the phonograph on $^{22}$. The rhetoric of perishability of archival objects, seems to justify the use of the metaphor of shelf-life in the very moment of collection. The perishability of the record itself is, however, not acknowledged in the impulse to archive. Efforts might after all be more directed towards a contingent assessment of the present than towards a future vision. The vision of the archive in its beginning years was only vaguely a time capsule idea for a later future ${ }^{23}$. The act of archival selection is in the first instance bound to the recently past event by 
capturing it in an affordable medium. As such, memories are often immediately rehearsed and fed back into the theatre community through uses of the archive which I will elaborate on further below. To summarize, the initial move to archive was fairly tied into the «front of the house» policy through the contact with the theatre community and active debates about recent memories, something that can be understood as memory practice itself ${ }^{24}$. For the specific medium of sound it might be said, that the archive only gradually got ready to exploit the possibilities of sound. This starting difficulty might also be reflected in the fact, that responsibilities of recording, re-listening, editing and shelving are shared; hiring a sound specialist was considered only two years into the project $^{25}$.

\section{Functionality and uses of the archive - Functional memory?}

Memory needs practice to function as remembering, and not as storing ${ }^{26}$. Let me pick selected instances of use in regard to which temporal strategies they might employ. One type of use, I would like to abstract as a «historicizing use of current past». To pick, somewhat at random, one from a number of possible examples, in the course of a popular public lecture series Visie op toneel (Outlook on theatre) in 1971, Adrian Brine, actor and director, held a workshop in which - according to corresponding news coverage - he used audio and video material from the archive to illustrate the transition from one Chekhov performance tradition to another ${ }^{27}$. Such a use of relative real-time material in sound format might have entertained the listener at the occasion in the mode of a nonprofessional lecture. Anniversaries are popular occasions, for this type of use. In that sense the sound format is not necessarily central. On the one hand, material theatre heritage of the Netherlands was centrally collected by the former TIN institute, so even incompletely catalogued sound formats might be compensated by corresponding material in other formats for indefinite use - if the material condition allows for it. On the other hand, the approach of recording "great» performances, might not always be traceable if their greatness is not reflected in an accompanying selection document nor into already rehearsed historiographies ${ }^{28}$.

Some of the uses were emphatically linked with the archive's recording practice and feature Theater Klank en Beeld's registrations at corresponding festivals such as Kijkspel (Spectacle) 1967, and Theater in het warenhuis - Uit dit seizoen (Theatre in the shopping mall - From this season) (1972), both occasions for which not only short performances were given live, but also replayed ${ }^{29}$. In these aforementioned instances of reuse of archival material performances are replayed publicly in the same theatre season in which they premiered and can arguably be seen to evoke recent shared memories, either embedded in an argument in the case of Adrian Brine's lectures, or in instances that celebrate the recapitulation as an end in itself.

16 Far removed from this assumed shared theatre memory, I initiated a permanent «sound shower» installation displaying alternating audio documents under the name «volatile listening» (vluchtig luisteren) in the entrance hall of the Amsterdam Theatre Studies Institute in June 2016. As a way to bring the material back to attention, in a mixture between a simple interface into the archive's material and current attempts to archival art, in which the archival condition itself is reflected, the installation is an emphatic 
monument to both, the archive's and the theatre material's ephemerality, and at the same time an open-ended chance for the student of theatre to become aware of the archive as well as of particular singular sources ${ }^{30}$.

17 I suggest to see both aforementioned types of reuse of archival material as variations of life-forms on and off «the shelf» in regards to the memory practices as which they might be discussed. These exposures of archival material to the «public ear ${ }^{31}$ » might evade a simple linearity of memory formation, not only through its institutional specificity.

\section{Conclusion}

It might be a misapprehension to think that intentions become determinately readable in the archive in its entire body. In fact, not engaging with singular sources, but an entire institution might be deceptive and not ultimately practicable. However, it can be regarded as an inactive backdrop, and as such life on the shelf is still thinkable and holds potential to (re-)shape collective memory ${ }^{32}$. The use of sound recordings for historiographical research purposes reaches its limit when a sound recording is not catalogued and not further identifiable and no other archival material is relatable.

I suggested to frame this article in terms of (the limits of) shelf-life, acknowledging explicitly the officially labeled dysfunctionality of an incomplete collection. However, this might raise the question whether my implicit goal is to fill the gaps and fix the archive's flaws ${ }^{33}$. I would like to respond to this by means of a concluding elaboration on the selflife metaphor: The hope behind focusing on the institutional constructions and labels is a methodological choice to understand an archiving policy and as such delineating and possibly limiting factors. The question about the engagement with «life on the shelf» is a reversal of the original metaphor to complicate the focus on the limits. After all: which kinds of traces will be left by our research on the lives on the shelf?

\section{BIBLIOGRAPHIE}

Assmann, Aleida, Erinnerungsräume. Formen und Wandlungen des kulturellen Gedächtnisses [Memory spaces. Forms and changes of cultural memory], Munich, C.H. Beck, 1999.

-, «Speichern oder Erinnern? Das kulturelle Gedächtnis zwischen Archiv und Kanon» [Storing or Remembering? Cultural Memory between Archive and Canon], in M. Csáky (Ed.), Speicher des Gedächtnisses: Bibliotheken, Museen, Archive [Storage of memory: libraries, museums, archives], Vienne, Passagen-Verlag, 2001, p. 15-29.

Chun, Wendy Hui Kyong, «The Enduring Ephemeral, or the Future Is a Memory», Critical Inquiry, 35 (1), 2008, p. 148-171.

Cook, Terry, «Remembering the Future. Appraisal of Records and the Role of Archives in Constructing Social Memory», in F. X Jr. Blouin and W. G. Rosenberg (Ed.), Archives, Documentation, and Institutions of Social Memory. Essays from the Sawyer Seminar, Michigan, University of Michigan Press, 2007, p. 169-181. 
Derrida, Jacques and Eric Prenowitz, Archive Fever: A Freudian Impression, Chicago, University of Chicago, 1996.

Dreckmann, Kathrin, «Verba volant, scripta manent. Das kulturelle Gedächtnis und die Archivierung des Akustischen» [Verba volant, scripta manent. Cultural memory and archiving the auditory], in R.-E. Mohrmann (Ed.), Audioarchive. Tondokumente Digitalisieren, Erschließen und Auswerten (Audio Archives. Digitalization, Appraisal and Evaluation of Audio Documents), Münster, Waxmann, 2013, p. 9-23.

Eilander, Maarten, Het Geluids. En Beeldarchief Van Het Theaterinstituut (The Archive for Sound and Image of the Dutch Theatre Institute), unpublished working paper, Amsterdam, 2009.

Erenstein, Rob, Een Theatergeschiedenis Der Nederlanden: Tien Eeuwen Drama En Theater in Nederland En Vlaanderen (Theatre History of the Netherlands: Ten Centuries of Drama and Theatre in the Netherlands and Flanders), Amsterdam, Amsterdam UP, 1996.

Foster, Hal, «An Archival Impulse», October, n¹10, 2004, p. 3-22.

Franzen, Ricarda, «Ausheulen und Neu Anfangen? Die Abwicklung Des Theater Instituut Nederland und Seines Museums» [Have a good cry and start anew? The dissolution of the Dutch Theatre Institute and its museums], Double: Magazin Für Puppen-, Figuren- Und Objekttheater, vol. 2, 2013, p. 17-19.

Gross, Daniel M., «Listening Culture», in I. A. Strecker and S. A. Tyler (Ed.), Culture \& Rhetoric, Berghahn Books Studies in Rhetoric and Culture I, New York, Berghahn, 2009, p. 59-73.

Hoefnagels, Lou, «Theatre Sound and Image - Archives of Tapes and Films Relating toTheatre», Recorded Sound 33-40 (1969-70), p. 526-28.

—, Theater Klank En Beeld [Theatre Sound and Image], Amsterdam, Stichting IVIO, 1971.

-, «Theatre on Tape», IASA Phonographic Bulletin 4, 1972, p. 20-22.

Holzapfel, Jan-Philipp, «Man gibt mir drei Minuten, um mich an die Zukunft zu wenden - Zur Gründung des dänischen Staatsarchivs für historische Filme und Stimmen 1913» [I was given three minutes to speak to the future - About the founding of the Danish State Archive for historical films and voices 1913], in R.-E. Mohrmann (Ed.), Audioarchive. Tondokumente Digitalisieren, Erschließen Und Auswerten, op. cit., p. 61-74.

Ketelaar, Eric, «The Archive as a Time Machine», Proceedings of the DLM-forum 2002: @ccess and Preservation of Electronic Information: Best Practices and Solutions: Barcelona, 6-8 May 2002, Luxembourg, Office for Official Publications of the European Communities, 2002, p. 576-581.

Knoop, Riemer, «An Empty Stage. Assessing the Value of Theatrical Collections», in B. Forment and C. Stalpaert (Ed.), Theatrical Heritage: Challenges and Opportunities, Leuven, Leuven UP, 2015, p. $179-195$.

\section{Newspapers articles}

«Geluidsopnamen van Toneelstukken» [Sound recordings of theatre texts], De Tijd [The Time], June 7, 1967.

«Voor het eerst aandacht voor dramaturgie aan RU» [For the first time attention for dramaturgy at the RU], Nieuwsblad van het Noorden (Newspaper of the North), September 22, 1971.

[newspaper article without title], De Waarheid [The Truth], September 28, 1972. Boswinkel, Willem, «Heijermans Schakels prachtig op plaat» [Heijermans (theatre text) Schakels beautiful on record], NRC, January 4, 1975. 


\section{Online ressources}

«Audioarchief», Theatercollectie Bijzondere Collecties (Stichting TiN), last accessed May 1, 2016. http://theaterencyclopedie.nl/wiki/Audioarchief

«Geluidsopnames theaterhistorie te horen in de hal van het Universiteitstheater» (Sound recordings - theatre history on display in the entrance hall of the University Theatre), Theatercollectie Bijzondere Collecties (Stichting TiN), last accessed May 1, 2016. http://tin.nl/ geluidsopnames-theaterhistorie-te-horen-de-hal-van-het-universiteitstheater/

«IASA - 40 Years: An Overview», Ilse Assmann et al. (Ed.), 2009, last accessed May 1, 2016. http:// www.iasa-web.org/sites/default/files/40years/iasa/intro_cont.html

\section{NOTES}

1. W. Boswinkel, «Heijermans Schakels prachtig op plaat» (my translation).

2. W. H. K. Chun, «The Enduring Ephemeral, or the Future Is a Memory», p. 158.

3. J. Derrida, and E. Prenowitz, Archive Fever: A Freudian Impression, p. 7, italics in the original.

4. A. Assmann, Erinnerungsräume. Formen und Wandlungen des kulturellen Gedächtnisses.

5. More information (in Dutch) on the website of the overarching institution, «Audioarchief», last accessed May 1, 2016, http://theaterencyclopedie.nl/wiki/ Audioarchief

6. The overarching institution of the Theatre Institute is historically the only Dutch theatre museum. In its institutional history it has undergone several institutional reformations. In its current formation it is called «Theatercollectie Bijzondere Collecties (Stichting TiN)».

7. See for brief overviews and assessments of the dissolution: R. Franzen, «Ausheulen und Neu Anfangen? Die Abwicklung Des Theater Instituut Nederland und Seines Museums», p. 17-19; as well as R. Knoop, «An Empty Stage. Assessing the Value of Theatrical Collections», p. 179-195.

8. R. Knoop, «An Empty Stage. Assessing the Value of Theatrical Collections», p. 186.

9. A. Assmann, «Speichern oder Erinnern? Das kulturelle Gedächtnis zwischen Archiv und Kanon», p. 15-29; and K. Dreckmann, «Verba volant, scripta manent. Das kulturelle Gedächtnis und die Archivierung des Akustischen», p. 9-23.

10. M. Eilander, Het Geluids-En Beeldarchief Van Het Theaterinstituut.

11. Three of the publications will be used. Whereas the first one is a more extensive booklet in Dutch, the second and third publications are brief articles. L. Hoefnagels, Theater Klank En Beeld; L. Hoefnagels, «Theatre on Tape», p. 20-22; L. Hoefnagels, «Theatre Sound and Image - Archives of Tapes and Films Relating to Theatre», p. 526-28.

12. IASA was founded 1969 in Amsterdam, partially hosted by the institutional home of Theater Klank en Beeld. «IASA - 40 Years: An Overview», I. Assmann et al. (ed.), http:// www.iasa-web.org/sites/default/files/40years/iasa/intro_cont.html, last accessed May 1, 2016.

13. L. Hoefnagels, «Theatre Sound and Image - Archives of Tapes and Films Relating to Theatre», p. 527.

14. While in the context of the institutional setting the non-commercial interests prevail, there are other traces of an attempt to commercially exploit the contemporary text based theatre tradition as original idea for the archive, an attempt for which the entrance 
example might be said to still bear witness. According to the sound archive's internal document, the story of foundation was originally inspired by commercial LP's featuring performances of theatre pieces by Molière in France. The document elaborates on the background of a predecessor to the aforementioned director of the sound archival institution Lou Hoefnagels, a sound enthusiast called Gerard Piesaar with an overall love for technical recording technology, an appreciation of the "great voices» of his day and an extensive network in the theatre world (M. Eilander, Het Geluids. En Beeldarchief Van Het Theaterinstituut). His recording efforts are also anecdotally recalled in one of the archive's holdings, a 98 minutes interview with the widow of Piesaar and Lou Hoefnagels in older age (in 1988). And whereas the multiple founding rationales are worth studying in themselves, in what follows I would like to focus on the sound archive's early selection policy.

15. Hoefnagels holds that the quantity of material might not always be representative for any vision nor relatable to any dominant practice of its time, instead the composition of it is indebted to a particular material donation from private or professional entities. Theater Klank en Beeld, p. 6.

16. Ibid., p. 10.

17. Knoop, for his part, points out that the overall focus in the acquisition policy on theatre productions is different to comparable theatre collections such as «the theatrical holdings of the V\&A [Victoria and Albert Museum], where the collections are arranged along three clear acquisition lines - productions, buildings (houses) and biographies (plus some archives of extraordinary individuals» (Knoop, op. cit., p. 184).

18. L. Hoefnagels, Theater Klank en Beeld, p. 8.

19. Ibid., p. 11.

20. K. Dreckmann, «Verba volant, scripta manent. Das kulturelle Gedächtnis und die Archivierung des Akustischen», p. 15.

21. L. Hoefnagels, «Theatre Sound and Image - Archives of Tapes and Films Relating to Theatre», p. 526.

22. One of the examples being Erich Hornbostel's speech in Vienna 1905 in which he phrased most explicitly: «[...] Wir müssen retten, was zu retten ist.», Hornbostel in Dreckmann, p. 14-15.

23. See for a most explicit example of a sound archive as a time capsule a Danish archive discussed in: J.-P. Holzapfel, «Man gibt mir drei Minuten, um mich an die Zukunft zu wenden - Zur Gründung des dänischen Staatsarchivs für historische Filme und Stimmen 1913», p. 61-74. The metaphor of a time machine is alluded to in many articles discussing archives or archival ideas. To name only two: T. Cook, «Remembering the Future.

Appraisal of Records and the Role of Archives in Constructing Social Memory", p. 169-181; E. Ketelaar, «The Archive as a Time Machine», p. 576-81.

24. A. Assmann, «Speichern oder Erinnern? Das kulturelle Gedächtnis zwischen Archiv und Kanon».

25. «De Historie in een reeks data», archival document, December 11, 1971.

26. A. Assmann, «Speichern oder Erinnern?».

27. «Voor het eerst aandacht voor dramaturgie aan RU», Nieuwsblad van het Noorden, September 22, 1971.

28. I have not been able to find evidence of uses for academic research.

29. «Geluidsopnamen van Toneelstukken», De Waarheid. 
30. "Geluidsopnames theaterhistorie te horen in de hal van het Universiteitstheater», Theatercollectie Bijzondere Collecties (Stichting TiN), last accessed May 1, 2016. http:// tin.nl/geluidsopnames-theaterhistorie-te-horen-de-hal-van-het-universiteitstheater/ 31. D. Gross, «Listening Culture».

32. A. Assmann, Erinnerungsräume. Formen und Wandlungen des kulturellen Gedächtnisses, et «Speichern oder Erinnern? Das kulturelle Gedächtnis zwischen Archiv und Kanon».

33. Much of current archival art is focused on revealing the gaps in the archive. As Hal Foster puts it: «an allegory of archival work - as sometimes melancholic, often vertiginous, always incomplete.» (H. Foster, «An Archival Impulse», p. 12).

\section{RÉSUMÉS}

Cet article met en perspective l'institutionnalisation des mémoires du théâtre vocal à l'exemple des archives sonores historiques du théâtre néerlandais, fondées en 1965, connues à l'époque comme le «Theater Klank en Beeld». Après des décennies de collecte et d'archivage, le fonds s'avèra en mal de fonctionnement, bien avant que ne fût dissous le musée du théâtre dont il relevait. Sous la métaphore de la durée limitée de conservation en stock, les paradoxes mémoriaux apparemment à l'œuvre dans l'archivage du théâtre sonore, sont examinés à l'aune de leur organisation temporelle et institutionnelle. Afin de théoriser l'archivage et la réutilisation de documents sonores théâtraux, on examinera, dans le contexte des théories de la mémoire, des actes spécifiques de stockage et de réutilisation.

This article examines the institutionalization of phonic theatre memories at the example of the historical Dutch theatre sound archive, founded in 1965 and at the time known under the name «Theater Klank en Beeld». After decades of collecting and archiving, the collection was rendered dysfunctional, long before the dissolution of the theatre museum it pertained to. Under the metaphor of limited shelf-life the memory-related paradoxes seemingly implicit to theatre sound archiving are considered in regards to their temporal and institutional organization. In order to theorize the archiving and re-use of theatre sound documents, particular acts of «shelving» and reuse will be considered against the background of memory theories.

\section{INDEX}

Mots-clés : archivage du théâtre sonore, institutionnalisation de la mémoire, réutilisation des archives sonores, mémoire collective, durée de conservation en stock

Keywords : theatre sound archiving, institutionalization of memory, re-use of sound archives, collective memory, shelf-life 


\section{AUTEUR}

\section{RICARDA FRANZEN}

Doctorante en études théâtrales, chargée de cours et coordinatrice du programme MA de dramaturgie, département des Études théâtrales de l'Université d'Amsterdam.

Parmi ses publications :

«Ausheulen und Neu Anfangen? Die Abwicklung Des Theater Instituut Nederland und Seines Museums» (Have a good cry and start anew? The dissolution of the Dutch Theatre Institute and its museums), Double: Magazin Für Puppen-, Figuren- Und Objekttheater, vol. 2, 2013, p. 17-19.

«In and out of Earsight - Listening to historical Theatre Sound Recordings» in D. Roesner et A. Curtin (dir.), Sounds good, Special issue of Theatre and Performance Design, vol. 2, issue 3-4, automne/ hiver 2016, http://dx.doi.org/10.1080/23322551.2016.1231397 